\title{
Study of Zooplankton Species Structure and Dominance in Anzali International Wetland
}

\author{
Delaram Golmarvi', Maryam Fallahi Kapourchali ${ }^{2}$, Ali Mashinchian Moradi ${ }^{1}$, \\ Mohammadreza Fatemi', Rezvan Mousavi Nadoshan ${ }^{1}$
}

\author{
${ }^{1}$ Department of Marine Biology, Science and Research Branch, Islamic Azad University, Tehran, Iran \\ ${ }^{2}$ Inland water Aquaculture Center, Iranian Fisheries Science Research Institute (IFSRI), Agricultural Research Education and \\ Extension Organization (AREEO), Bandar-e Anzali, Iran \\ Email: ${ }^{*}$ m_fallahi2011@yahoo.com
}

How to cite this paper: Golmarvi, D., Kapourchali, M.F., Moradi, A.M., Fatemi, M. and Nadoshan, R.M. (2018) Study of Zooplankton Species Structure and Dominance in Anzali International Wetland. Open Journal of Marine Science, 8, 215-222. https://doi.org/10.4236/ojms.2018.82011

Received: December 25, 2017

Accepted: February 9, 2018

Published: February 12, 2018

Copyright $\odot 2018$ by authors and Scientific Research Publishing Inc. This work is licensed under the Creative Commons Attribution International License (CC BY 4.0).

http://creativecommons.org/licenses/by/4.0/

(c) (i) Open Access

\begin{abstract}
Anzali International wetland is one of the most important places for various organisms such as fishes. Zooplankton are the first consumers in the ecosystem, and they are perfect food for the larvae of fishes. The present study conducted monthly during January 2012 to December 2013 in 9 different stations with zooplankton population and chemical characteristics analysis such as water temperature ranged from $10^{\circ} \mathrm{C}-22^{\circ} \mathrm{C}, \mathrm{pH}$ determined alkaline nature of the wetland ranged from 7.05 to 9.47 , dissolved oxygen was recorded in the range of $3.36 \mathrm{mg} / \mathrm{l}$ to $10.51 \mathrm{mg} / \mathrm{l}$, nitrate was ranged between $0.48-4.36 \mathrm{mg} / \mathrm{l}$, total phosphates was between $0.15-0.67 \mathrm{mg} / \mathrm{l}$, salinity was recorded between 220 - $692 \mathrm{mg} / \mathrm{l}$, TDS was determined between $246-1971 \mathrm{mg} / \mathrm{l}$, BOD and COD was also recorded $2-36 \mathrm{mg} / \mathrm{l}$ and $4-74 \mathrm{mg} / \mathrm{l}$ respectively. Total 61 zooplankton species were found belonging to 4 groups: Protozoa (22 sp.), Rotatoria (29 sp.), Copepoda ( $5 \mathrm{sp}$.) and Cladocera (4 sp.). Rotatoria were found dominating other groups of zooplankton. Kruskal Wallis test showed that there was significant difference between density of zooplankton in different stations, months and seasons $(\mathrm{P} \leq 0.05)$ and significant differences were found between densities of different zooplankton phylum $(\mathrm{P} \leq 0.05)$. The water body is continuously receiving domestic discharge leading to large amount of nutrient inputs and high amount of phosphate and nitrate in the water body indicates that water is eutrophic in nature.
\end{abstract}

\section{Keywords}

Zooplankton, Diversity, Dominance, Anzali International Wetland

\section{Introduction}

Wetlands have played an important role for humankind in all continents. They 
are characterized by a large number of ecological niches and a significant percentage of biological diversity. Wetlands are among the most productive ecosystems in the world comparable to rainforests and coral reefs. Zooplankton community is cosmopolitan in nature and they inhabit all freshwater habitats of the world and their diversity and density refers to variety within the community. There are often important links in the transformation of energy from producers to consumers due to their large density, drifting nature, high group or species diversity and different tolerance to the stress [1]. Zooplankton diversity is one the most important ecological parameters as there is the intermediate link between phytoplankton and fish and plays a key role in cycling of organic materials in an aquatic ecosystem.

Due to their short life span, the zooplankton community often exhibits quick and dramatic changes in response to the change in the physicochemical properties of the aquatic environment. They do not only form an integral part of the lentic community but also contribute significantly to the biological productivity of the fresh water ecosystem. In the investigation, the data of zooplankton density and diversity in a moderate ecosystem of Anzali International wetland was studied monthly for one year, January 2012-December 2013 at 9 selected sites with 3 replicates.

\section{Materials and Methods}

\subsection{Study Area}

Present study has been carried out in Anzali wetland (Figure 1). This wetland

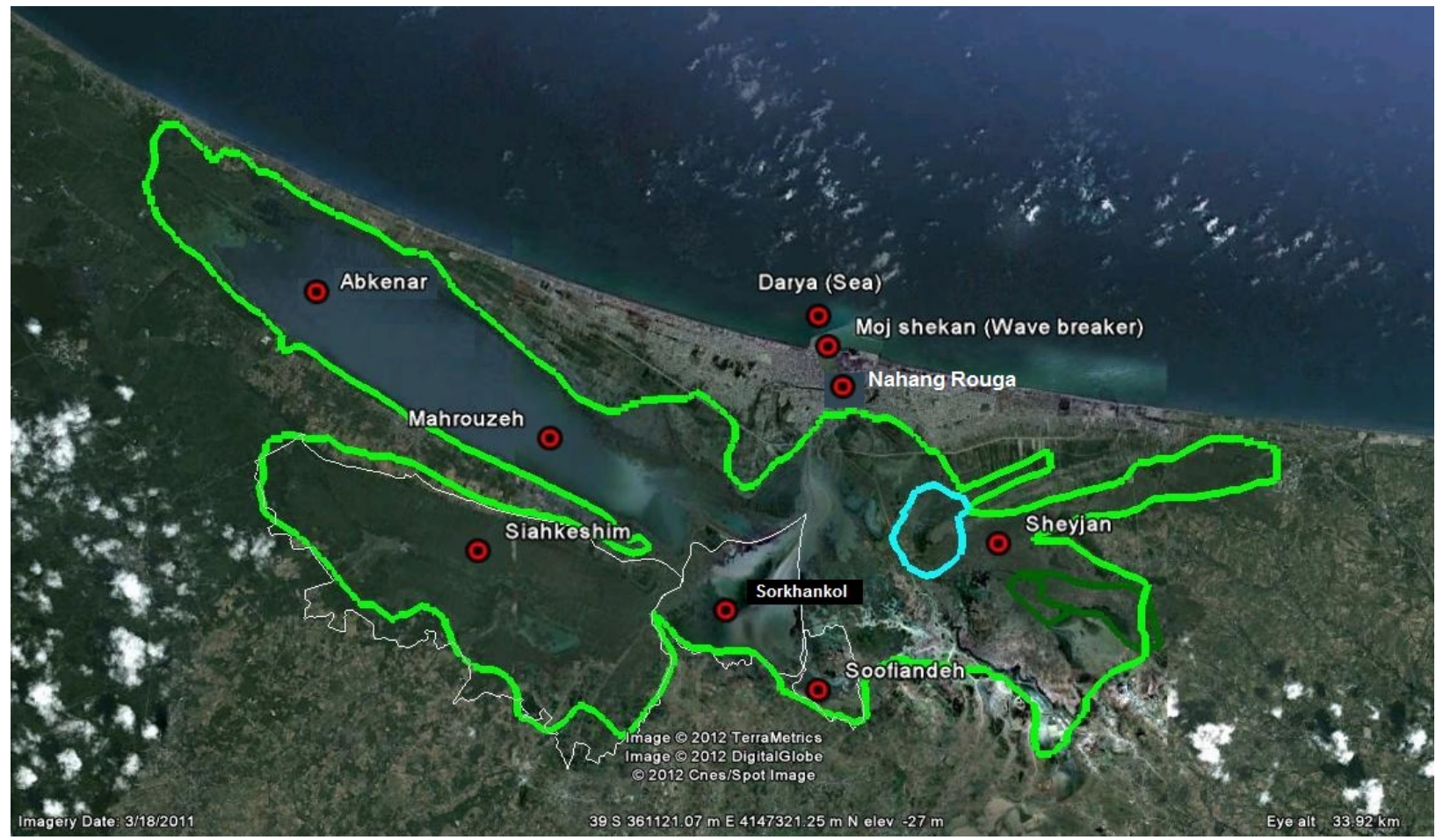

Figure 1. Sampling stations in Anzali wetland. 
lies between $49^{\circ} 55^{\prime} \mathrm{E}$ and $37^{\circ} 20^{\prime} \mathrm{N}$ of Gilan province, North of Iran. Total area of the wetland is approximately 15000 ha with maximum depth of about 1.2 meter. The water temperature rises up to $23^{\circ} \mathrm{C}$ during the month of May and falls below $10^{\circ} \mathrm{C}$ in January. The wetland is a principal source of food and fishing for local dependent communities of the rural areas, whilst household sewage and agricultural run-off from surrounding rice fields are discharged into it.

\subsection{Zooplankton Collection, Preservation, Identification and Density Analysis}

The samples of zooplankton were collected from each selected study site of this wetland for a period of one year (January 2012 to December 2013). The nylon Plankton net of conical shape and reducing cone of (30 $\mu$ mesh size) were used for collection of zooplankton. For a precise collection of zooplankton, the plankton net was towed in open water area of each site three times. After transferring the sample in air tight plastic bottles, it was carefully labeled and preserved immediately on site using 5\% formaldehyde. Later the collected samples were brought to the laboratory for identification of each genus, after that the density of zooplankton was calculated as per the lackey drop method [2].

\section{Result and Discussion}

The zooplankton population of Anzali wetland consisted of 61 various species of zooplankton (Table 1). The recorded species were categorized into 4 different groups as Protozoa, Rotatoria, Copepoda and Cladocera.

Diversity analysis revealed that Rotatoria dominated the zooplankton assemblage of Anzali wetland with 29 species. Protozoa also is dominated with 22 species and Copepoda were the third dominant group followed by 5 species and Cladocera were the forth group with 4 species.

Distinct peaks of Protozoa, Rotatoria, Copepoda and Cladocera were observed during spring and summer [3]. However, the minimum population of the groups was registered during winter (Figures 2-5).

The net zooplankton abundance increased during summers probably corresponding to the water quality, decaying vegetation increased levels of organic matter in the sediment and higher abundance of bacteria in the wetlands during this time (Table 2 and Table 3) [4] [5]. Sudden reduction in the zooplankton population during the winter as noticed in the present finding could be due to sudden fall of temperature and dilution in concentration of minerals and salts in wetland water (Figure 6 and Figure 7) [6].

Qualitative dominance of Rotatoria over other zooplankton assemblages has been observed in Anzali wetland. Similar observations have been obtained [7] [8]. Summer peak obtained for Rotatoria members in the Anzali wetland was observed may be due to optimal nutrient and temperature conditions and lower DO contents in this season. Low Rotatoria density during the cold season can be attributed to turbulence generated by the excess water flow during the season 
Table 1. Identified zooplankton species in Anzali wetland.

\begin{tabular}{|c|c|c|c|}
\hline Number & Species & Number & Species \\
\hline 1 & Arcella arenaria & 31 & Philodina erythrophthalma \\
\hline 2 & Arcella costata & 32 & Filinia longiseta \\
\hline 3 & Tintinnopsis sinensis & 33 & Monostyla cornuta \\
\hline 4 & Tintinnopsis conicus & 34 & Monostyla hamata \\
\hline 5 & Tintinnopsis cratera & 35 & Lepadella patella \\
\hline 6 & Tintinnopsis lacustris & 36 & Lepadella ovalis \\
\hline 7 & Tintinnidium entzii & 37 & Lecane curvicornis \\
\hline 8 & Tintinnidium wangi & 38 & Lecane lodwigii \\
\hline 9 & Difflugia acuminate & 39 & Epiphanes brachionus \\
\hline 10 & Difflugia oblonga & 40 & Synchaeta pectinata \\
\hline 11 & Difflugia oviformis & 41 & Synchaeta vorax \\
\hline 12 & Difflugia lebes & 42 & Synchaeta stylata \\
\hline 13 & Euglypha alveolata & 43 & Synchaeta oblonga \\
\hline 14 & Euglypha tuberculata & 44 & Trichocera pussilla \\
\hline 15 & Actinosphaerium eichhornii & 45 & Trichocera porcellus \\
\hline 16 & Centropyxis aculeata & 46 & Coulrella adriatica \\
\hline 17 & Cyphoderia alveolata & 47 & Euchalanis diltata \\
\hline 18 & Paramecium caudatum & 48 & Lophocharis oxysternon \\
\hline 19 & Amoeba polypodia & 49 & Dissotrocha aculeata \\
\hline 20 & Marituja pelagica & 50 & Trichotria tetractis \\
\hline 21 & Trinemalineare & 51 & Trichotria pocillum \\
\hline 22 & Vorticella campanula & 52 & Testudinella patina \\
\hline 23 & Polyarthra dolichoptera & 53 & Naplious copepoda \\
\hline 24 & Polyarthra vulgaris & 54 & Nematoda \\
\hline 25 & Brachionus calyciflorus & 55 & Cyclops vicinus \\
\hline 26 & Brachionus angularis & 56 & Cyclops scutifer \\
\hline 27 & Brachionus variabilis & 57 & Thermocyclops dybwskii \\
\hline 28 & Brachionus rubens & 58 & Alona rectangular \\
\hline 29 & Keratella quadrata & 59 & Alona costata \\
\hline \multirow[t]{2}{*}{30} & Cephalodella gibba & 60 & Bosmina coregoni \\
\hline & & 61 & Bosmina longirostris \\
\hline
\end{tabular}

[9]. Dominance of Copepoda among zooplankton peak was found during summer might be due to optimal thermal and nutritional conditions and lower concentration of oxygen [10]. Effect of rains may explain low records of Cladocera from November to March. Copepods developed better in warm periods as noticed in the present study. Lesser abundance of copepods as recorded in the present study had also been observed [11] [12]. The low abundances of copepods in Anzali wetland appear to be due to mainly predation pressure from fishes [13]. 
Table 2. Significant difference of zooplankton densities in different seasons.

\begin{tabular}{cc}
\hline Group & Number \\
\hline 1) Chi-Square & 599.322 \\
df & 11 \\
Asymp.Sig. & 0.000 \\
2) Chi-Square & 541.913 \\
df & 11 \\
Asymp.Sig. & 0.000 \\
3) Chi-Square & 240.503 \\
df & 11 \\
Asymp.Sig. & 0.000 \\
4) Chi-Square & 82.222 \\
df & 9 \\
Asymp.Sig. & 0.000 \\
\hline
\end{tabular}

Table 3. Significant difference of zooplankton densities in different stations.

\begin{tabular}{cc}
\hline Group & Number \\
\hline 1) Chi-Square & 51.671 \\
$\mathrm{df}$ & 8 \\
Asymp.Sig. & 0.000 \\
2) Chi-Square & 43.727 \\
$\mathrm{df}$ & 8 \\
Asymp.Sig. & 0.000 \\
3) Chi-Square & 28.456 \\
$\mathrm{df}$ & 8 \\
Asymp.Sig. & 0.000 \\
4) Chi-Square & 13.972 \\
$\mathrm{df}$ & 7 \\
Asymp.Sig. & 0.000 \\
\hline
\end{tabular}

Seasonal average of allgroups in spring

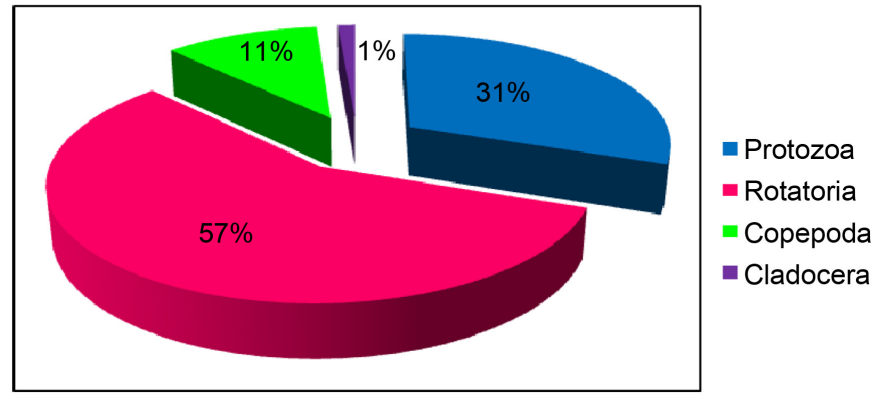

Figure 2. Seasonal average of all groups in spring.

In general, it can be concluded that in Anzali wetland like other similar ecosystems in the world, zooplankton society has mainly contained Rotatoria, Protozoa, Copepoda and Cladocera, among them, Rotatoria and Protozoa have been observed more than other groups [14] [15]. The dominant group of zooplankton communities of Anzali wetland is Rotatoria. The result of the survey by 
Seasonal average of all groups in summer

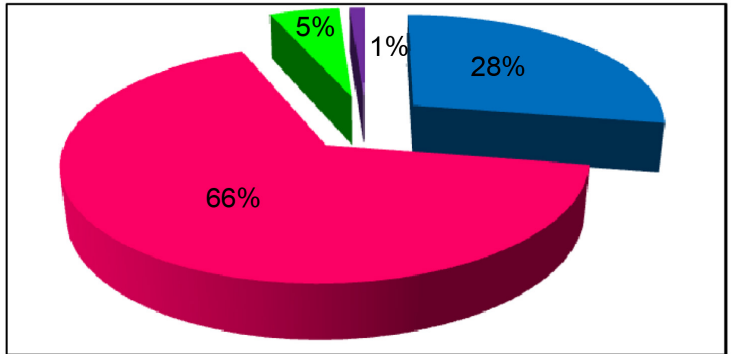

-Protozoa

-Rotatoria

Copepoda

-Cladocera

Figure 3. Seasonal average of all groups in summer.

Seasonal average of all groups in Autumn

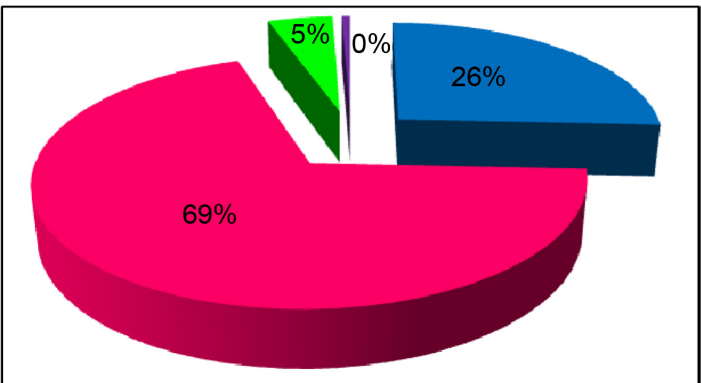

- Protozoa

- Rotatoria

- Copepoda

- Cladocera

Figure 4. Seasonal average of all groups in autumn.

Seasonal average of all seasons in winter

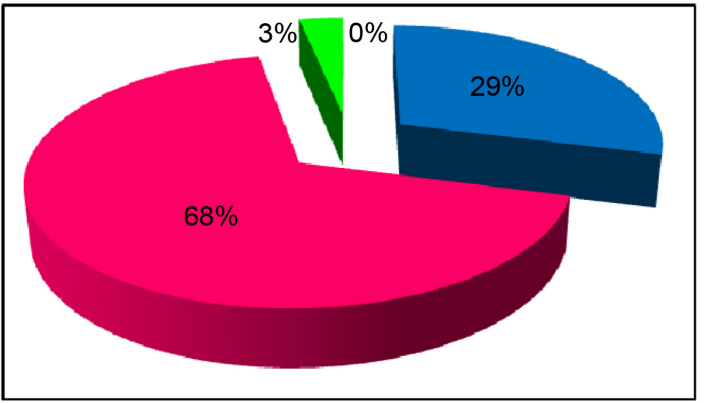

- Protozoa

- Rotatoria

- Copepoda

- Cladocera

Figure 5. Seasonal average of all seasons in winter.

\section{Time variation of species density}

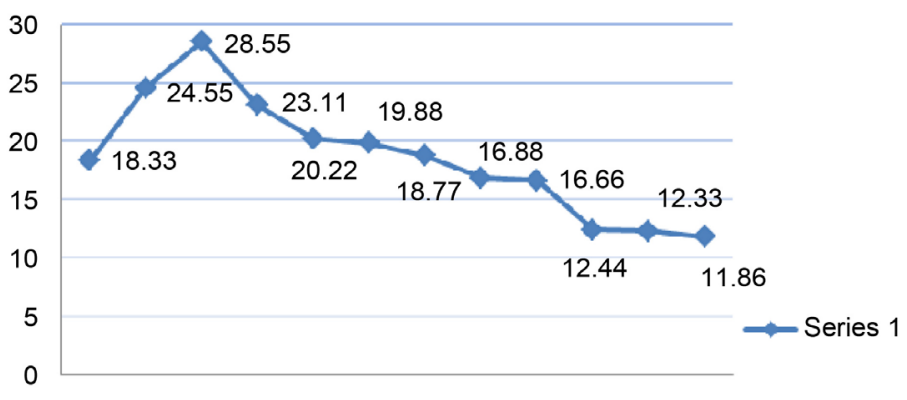

Apr May Jun July Aug Sept Oct Nov Dec Jan Feb Mar

Figure 6. Time variation of species density. 


\section{Spatial variation of species density}

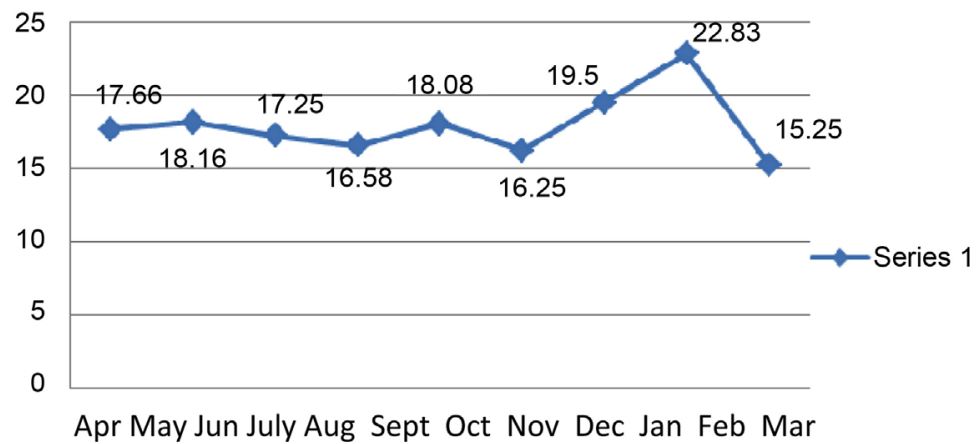

Figure 7. Spatial variation of species density.

Consultant Engineering group showed that Rotatoria, Protozoa and Copepoda were the dominant groups of Anzali wetland which has been approved by other researches [16]. Finally, it was confirmed that although the rate of changes in abundance and diversity of zooplankton groups are nearly close in different stations and season but east and central part of the wetland have less population and diversity due to increasing amount of pollution in these areas.

\section{References}

[1] JICA, DOE, MOJA (2004) The Study on Integrated Management for Ecosystem Conservation of the Anzali Wetland in the Islamic Republic of Ira. Draft Final report Vol. II: Maim Report. Nippon Koei Co., Tokyo, 721 p.

[2] American Public Health Association (2005) Standard Methods for Examination Water \& Wastewater. In: Eaton, A.D., Clescer, L.S., Rice, E.W. and Greenberg, A.E., Eds., 21st Edition, Port City Press, Baltimore, MA, 4-100.

[3] Carling, K.J., Ater, I.M., Pellam, M.R., Bouchard, A.M and Miluc, T.B. (2004) A Guide to the Zooplankton of Lake Champlain. Scientia Discipulorum-Journal of Undergraduate Research, 1, 1-29.

[4] Hans, M.N. and Anj, K. (2007) Reginal Zooplankton Taxonomy and Identification Training Workshop. Swakopmund, 8-19 January 2007, 2-4.

[5] Holcik, J. and Olah, J. (1992) Fish, Fisheries and Water Quality in Anzali Lagoon and Its Watershed. Report Prepared for the Project-Anzali Lagoon Productivity and Fish Stock Investigations. Food and Agriculture Organization, Rome, FI, 109 p.

[6] Sivakami, R., Sugumar, P., Sumithra, P. and Amina, S. (2013) Rotifer Diversity and Its Seasonal Variation of Two Perennial Temple Ponds of Tiruchirapplli, Tamil Nadu. Asia Pacific Journal of Research, 2, 157-162.

[7] Sulehria, A.Q.K., Ejaz, M., Mushtaq, R. and Saleem, S. (2013) Analysis of Planktonic Rotifers by Shannon-Weaner Index in Muraliwala (Distt. Gujranwala). Pakistan Journal of Science, 65, 15-19.

[8] Witty, L.M. (2004) Practical Guide to Identifying Freshwater Crustacean Zooplankton. 2nd Edition, Cooperative Freshwater Ecology Unit, Sudbury, 50 p.

[9] Mulani,S.K., Mule, M.B. and Patil, S.U. (2006) Studies on Water Quality and Zooplankton Community of Panchganga River in Kolhapur City. Journal of Environmental Biology, 30, 455-459. 
[10] Webber M., Edwards-Myers, E., Campbell, C. and Webber, D. (2005) Phytoplankton and Zooplankton as Indicators of Water Quality in Discovery Bay Jamaica. $\mathrm{Hy}^{-}$ drobiologia, 545, 177-193. https://doi.org/10.1007/s10750-005-2676-X

[11] Ferdous, Z. and Muktadir, A.K.M. (2009) A Review: Potentiality of Zooplankton as Bioindicator. American Journal of Applied Sciences, 6, 1815-1819. https://doi.org/10.3844/ajassp.2009.1815.1819

[12] Haberman, J. and Haldan, M. (2014) Indices of Zooplankton Community as Valuable Tools in Assessing the Trophic State and Water Quality of Eutrophic Lakes: Long Term Study of Lake Vortsjarv. Journal of Limnology, 73, 263-273. https://doi.org/10.4081/jlimnol.2014.828

[13] Nogueria, M.G. (2001) Zooplankton Composition, Dominance and Abundance as Indicators of Environmental Compartmentalization in Jurumirim Reservoir (Parananapema River), Sao Paulo, Brazil. Hydrobiologia, 455, 1-18. https://doi.org/10.1023/A:1011946708757

[14] Altindag, A., Buyurgan, O., Kaya, M., Ozdemir, E. and Dirican, S. (2009) A Survey on Some Physicochemical Parameters and Zooplankton Structure in Kaeraman Stream, Antalya, Turkey. Journal of Animal and Veterinary Advances, 8, 1710-1716.

[15] Baiao, C. and Boavia, M.J. (2005) Rotifers of Portuguese Reservoirs in River Tejo Catchment: Relations with Trophic State. Limnetica, 24, 103-114.

[16] Didinen, H. and Boyaci, Y.O. (2007) Determination on Base Systematic and Ecology of Rotifer Fauna (Rotifera) in Hoyran Region of Eğirdir Lake. Ege Journal of Fisheries and Aquatic Sciences, 24, 31-37. 